Available online at GSC Online Press Directory

GSC Biological and Pharmaceutical Sciences

e-ISSN: 2581-3250, CODEN (USA): GBPSC2

Journal homepage: https://www.gsconlinepress.com/journals/gscbps

(RESEARCH ARTICLE)

\title{
Ascophyllum nodosum extract on growth plants in Rebutia heliosa and Sulcorebutia canigueralli
}

\author{
Prisa Domenico* \\ CREA Research Centre for Vegetable and Ornamental Crops, Council for Agricultural Research and Economics, Via dei \\ Fiori 8, 51012 Pescia, PT, Italy.
}

Publication history: Received on 09 January 2020; revised on 13 January 2020; accepted on 14 January 2020

Article DOI: https://doi.org/10.30574/gscbps.2020.10.1.0007

\begin{abstract}
In this study an extract of Aschophyllum nodosum was used to improve growth and flowering in plants of Rebutia heliosa and Sulcorebutia canigueralli. The two experimental groups in cultivation were: i) group without the use of Ascophyllum nodosum (CTRL), irrigated with water and fertilized every two weeks; ii) group treated with 10\% Ascophyllum nodosum (AS) powder mixed with the substrate, irrigated with water and fertilized every two weeks. All plants treated with Ascophyllum nodosum showed a significant increase in the agronomic characteristics analysed. The cacti (Rebutia heliosa and Sulcorebutia canigueralli) grown in the algae treated substrate showed a significant increase in plant height, suckers number, vegetative and roots weight, plant circumference, flowers number and flower time and seed germination. Effects certainly due to an improvement in the nutritional status of the plants induced by an increase in nutrient assimilation, which manifests itself in increased stress tolerance. Positive effects can be found especially on plant species that have difficulty in germinating, rooting and flowering or as in this experiment on plants that are slow to grow or have difficulty in being grown in greenhouses and in climatic conditions different from those in which they originated.
\end{abstract}

Keywords: Cactus; Seaweed; Sustainable applications; Stimulation; Potted plants

\section{Introduction}

The genus Rebutia was described by K. Schumann in 1895 as a unique species ( $R$. minuscola), whose name was given in honour of Pierre Rebut (1827-1898) French wine producer and cactus merchant. As for many kinds of South American cactus it has given rise to many taxonomic discussions. Many species have been described, most of them not recognized. Schumann in 1897-98 reduced Rebutia, in his major monograph, to a subgenus of Echinocactus. It currently includes Sulcorebutia and Weingartia [1]. The genus belongs to the subfamily Cactoideae, tribe Trichocereae. Rebutia has rounded areoles at the top of the nipple, with triangular scales in the flower tube and unshakable fruits. It is divided into three sub-genres: Aylostera, spherical stem, with stamens and pistils welded to the base of the receptacle; Rebutia, spherical stem, stamens and pistils not welded to the receptacle and Mediolobivia, cylindrical stem, with stamens and pistils welded to the receptacle. Sulcorebutia has elongated areoles planted in the nipples, with the flower tube scales rounded in the shape of a heart and dehiscent fruits. It has a basal flowering, with only one flower per areola and unbranched funiculus. Rebutia is a small cactus, with a great variety of forms and spines, slow-growing, very often caespitose, globular or briefly cylindrical with a depressed apex, green stem, with missing or little pronounced ribs, and many spiral tubercles on whose apexes are located the areoles with small spines. The flowers are small, numerous, diurnal, campanuliform, lasting, close at night and open the following morning, the colour may be yellow, intense red, orange, white. The distribution goes from the east of the Andes, in little elevated zones close to the mountains of Bolivia, up to north-west of Argentina, between the 1000 and the 4000 metres of altitude; such an environment has a strong temperature range during the day, with strong exposure to the ultra-violet rays [2].

\footnotetext{
${ }^{*}$ Corresponding author

E-mail address: domenico.prisa@crea.gov.it
} 
Several studies have documented the potential of some commercially available substances and products to protect and improve the growth and physiological quality of ornamental plants and fruits $[3,4,5]$. Very few studies have been carried out on cacti and succulent plants. One of the most used products is the seaweed extract of Ascophyllum nodosum (L.), an excellent promoter of plant growth and nutrition [6], which accelerates seed germination and promotes plant settlement [7], increases the resistance of the treated plant to biotic and abiotic stresses [8] and activates the plant's resistance mechanisms [9]. Marine algae extracts are natural compounds, rich sources of nutrients and bioactive compounds. An expressive number of brown algae is already used in agriculture and sold as plant fertiliser [9]. Many jobs have already been developed with algae for disease control, but few have focused on improving the quality of cacti that are usually very slow in the growth phase.

In this study an extract of Aschophyllum nodosum was used to improve growth and flowering in plants of Rebutia heliosa and Sulcorebutia canigueralli (Figure 1).

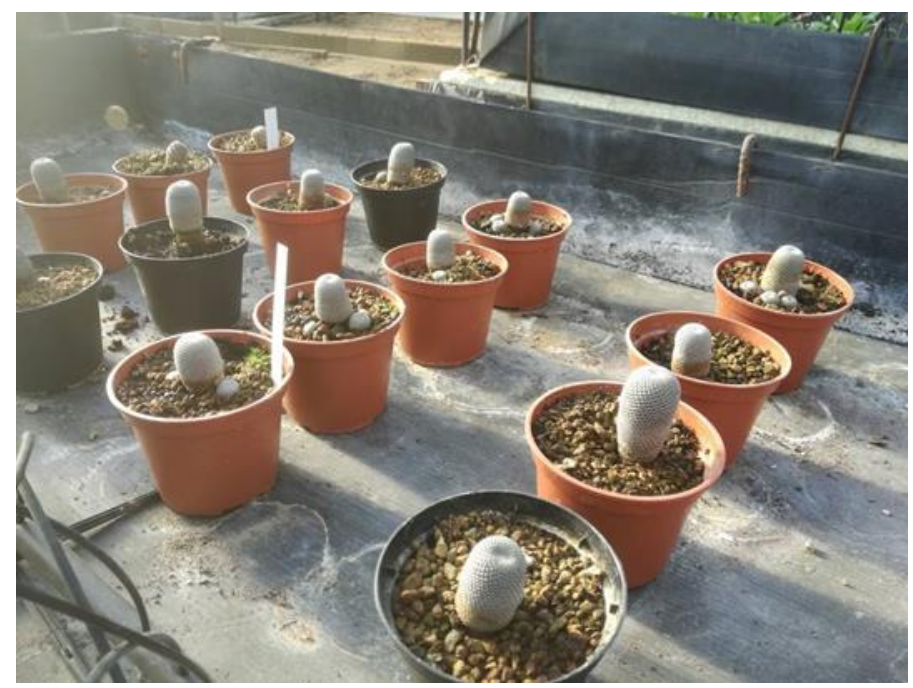

Figure 1 Details of Rebutia and Sulcorebutia plants

\section{Material and methods}

\subsection{Greenhouse experiment and growing conditions}

The experiments, started at the beginning of January 2019, were conducted in the greenhouses CREA-OF of Pescia (Pt), Tuscany, Italy ( $43^{\circ} 54^{\prime} \mathrm{N} 10^{\circ} 41^{\prime} \mathrm{E}$ ) on plants of Rebutia heliosa and Sulcorebutia canigueralli. The plants were placed in pots of $\varnothing 10 \mathrm{~cm} ; 30$ plants for each experimental thesis, divided into 3 replicas of 10 plants each. All plants were fertirrigated with NPK 5-5-7 fertiliser (once every two weeks). The 2 experimental groups in cultivation were:

- group without the use of Ascophyllum nodosum (CTRL), irrigated with water and fertilized every two weeks;

- group treated with 10\% Ascophyllum nodosum (AS) powder mixed with the substrate, irrigated with water and fertilized every two weeks;

For the algae product, Ecoalga ${ }^{\circledR}$ was used added to the growing substrate instead of spraying it on the vegetative part. The plants were irrigated with drip irrigation. Watering was activated by a timer whose program was adjusted weekly according to weather conditions and leaching fraction. On December 10, 2019, the plant height, number of new suckers, vegetative and root weight, flowers number and flowering time and plant circumference were recorded. The number of germinated seeds and the average germination time of rebutia and sulcorebutia in the two different types of substrate were also evaluated separately. Each experimental thesis was characterized by 5 replicas in which 50 seeds were placed in each.

\subsection{Statistics}

The experiment was carried out in a randomized complete block design. Collected data were analysed by one-way ANOVA, using GLM univariate procedure, to assess significant $(P \leq 0.05,0.01$ and 0.001$)$ differences among treatments. 
Mean values were then separated by LSD multiple-range test $(P=0.05)$. Statistics and graphics were supported by the programs Costat (version 6.451) and Excel (Office 2010).

\section{Results}

\subsection{Plant growth}

All plants treated with Ascophyllum nodosum showed a significant increase in the agronomic characteristics analysed. The cacti (Rebutia heliosa and Sulcorebutia canigueralli) grown in the algae treated substrate showed a significant increase in plant height, number of suckers, vegetative weight and roots, plant circumference, number of flowers and flower length.

In Rebutia heliosa, (Table 1) the plant height was $7.52 \mathrm{~cm}$ (AS), compared to $5.67 \mathrm{~cm}$ (CTRL) (Figure 2A). For the number of suckers, 5.33 (AS) compared to 0.33 of the untreated control (Figure 3A). There is a significant increase in vegetative biomass $12.03 \mathrm{~g}$ (AS) compared to $8.43 \mathrm{~g}$ of the untreated control. The same trend can be seen for root weights $7.03 \mathrm{~g}$ in (AS) compared to $4.98 \mathrm{~g}$ in the untreated control. The thesis with Ascophyllum nodosum showed a significant increase in plant circumference, $7.12 \mathrm{~cm}$ (AS) while $6.02 \mathrm{~cm}$ (CTRL), flower number 7.67 (AS) while 3.83 (CTRL) and flower duration 5.67 days while 4.50 days of the control (Figure 3B).

Even in Sulcorebutia canigueralli (Table 2), the height of the plants was 4, $87 \mathrm{~cm}$ (AS), compared to 3, $58 \mathrm{~cm}$ (CTRL). For the number of new suckers, 2.83 (AS) compared to 0.37 in the untreated control. There was a significant increase in vegetative biomass $3.43 \mathrm{~g}$ (AS) compared to $2.40 \mathrm{~g}$ in (CTRL) and in root biomass $3.28 \mathrm{~g}$ (AS) compared to $2.48 \mathrm{~g}$ (CTRL) (Figure 2B).

In Sulcorebutia canigueralli in the thesis with Ascophyllum nodosum there is also a significant increase in plant circumference $3.37 \mathrm{~cm}$ (AS) compared to $2.51 \mathrm{~cm}$ (CTRL), the number of flowers 5.00 (AS) compared to 3.68 (CTRL) and flower duration 4.51 days (AS) compared to 3.34 days of untreated control.

Table 1 Evaluation of Ascophyllum nodosum extract on plants of Rebutia heliosa

\begin{tabular}{cccccccc}
\hline Groups & $\begin{array}{c}\text { Plant } \\
\text { height } \\
\text { (cm) }\end{array}$ & $\begin{array}{c}\text { Suckers } \\
\text { number } \\
\mathbf{( n}^{\circ} \text { ) }\end{array}$ & $\begin{array}{c}\text { Vegetative } \\
\text { weight } \\
\text { (g) }\end{array}$ & $\begin{array}{c}\text { Root } \\
\text { weight } \\
\text { (g) }\end{array}$ & $\begin{array}{c}\text { Plant } \\
\text { circumference } \\
\text { (cm) }\end{array}$ & $\begin{array}{c}\text { Flower } \\
\text { number } \\
\left(\mathbf{n}^{\circ}\right)\end{array}$ & $\begin{array}{c}\text { Flowering } \\
\text { time } \\
\text { (days) }\end{array}$ \\
\hline CTRL & $5,67^{\mathrm{b}}$ & $0,33^{\mathrm{b}}$ & $8,43^{\mathrm{b}}$ & $4,98^{\mathrm{b}}$ & $6,02^{\mathrm{b}}$ & $3,83^{\mathrm{b}}$ & $4,50^{\mathrm{b}}$ \\
AS & $7,52^{\mathrm{a}}$ & $5,33^{\mathrm{a}}$ & $12,03^{\mathrm{a}}$ & $7,03^{\mathrm{a}}$ & $7,12^{\mathrm{a}}$ & $7,67^{\mathrm{a}}$ & $5,67^{\mathrm{a}}$ \\
\hline $\boldsymbol{A N O V A}$ & $* * *$ & $* * *$ & $* * *$ & $* * *$ & $* *$ & $* * *$ & $* *$
\end{tabular}

One-way ANOVA; n.s. - non significant; ${ }^{*}, * *, * *-$ significant at $\mathrm{P} \leq 0.05,0.01$ and 0.001 , respectively; different letters for the same element indicate significant differences according to Tukey's (HSD) multiple-range test $(\mathrm{P}=0.05)$

Table 2 Evaluation of Ascophyllum nodosum extract on plants of Sulcorebutia canigueralli

\begin{tabular}{|c|c|c|c|c|c|c|c|}
\hline Groups & $\begin{array}{l}\text { Plant } \\
\text { height } \\
\text { (cm) }\end{array}$ & $\begin{array}{c}\text { Suckers } \\
\text { number } \\
\left(n^{\circ}\right)\end{array}$ & $\begin{array}{c}\text { Vegetative } \\
\text { weight } \\
\text { (g) }\end{array}$ & $\begin{array}{c}\text { Root } \\
\text { weight } \\
\text { (g) }\end{array}$ & $\begin{array}{l}\text { Plant } \\
\text { circumference } \\
(\mathrm{cm})\end{array}$ & $\begin{array}{c}\text { Flower } \\
\text { number } \\
\left(n^{\circ}\right)\end{array}$ & $\begin{array}{c}\text { Flowering } \\
\text { time } \\
\text { (days) }\end{array}$ \\
\hline CTRL & $3,58^{b}$ & $0,37 \mathrm{~b}$ & $2,40 \mathrm{~b}$ & $2,40^{b}$ & $2,51^{b}$ & $3,68^{b}$ & $3,34^{b}$ \\
\hline AS & $4,87^{a}$ & 2,83 a & 3,43 a & 3,28 a & 3,37 a & 5,00 a & 4,51 a \\
\hline ANOVA & $* * *$ & $* * *$ & ** & * & $* * *$ & ** & ** \\
\hline
\end{tabular}

One-way ANOVA; n.s. - non significant; ${ }^{* * *, * * *}$ - significant at $\mathrm{P} \leq 0.05,0.01$ and 0.001 , respectively; different letters for the same element indicate significant differences according to Tukey's (HSD) multiple-range test $(\mathrm{P}=0.05)$ 
An evaluation of the number of seeds and the average germination time of Rebutia heliosa and Sulcorebutia Canigueralli in a substrate treated with Ascophyllum nodosum was also carried out.

In Rebutia heliosa (Table 3) 39,50 seeds germinated in (AS) compared to 32,67 seeds in the untreated control. While 31.67 seeds are germinated in (AS) compared to 22.83 seeds of the (CTRL) in Sulcorebutia Canigueralli.

On the other hand, a significant reduction of the average germination time in Rebutia heliosa in the thesis with Ascophyllum, 17.83 days (AS) compared to 21.17 days of the control, was noted (Table 4). There were no significant differences in average germination time in Sulcorebutia.

Table 3 Evaluation of the number of germinated seeds of Rebutia heliosa and Sulcorebutia canigueralli

\begin{tabular}{ccc}
\hline Groups & $\begin{array}{c}\text { Rebutia } \\
\text { heliosa } \\
\mathbf{( n}^{\circ} \mathbf{)}\end{array}$ & $\begin{array}{c}\text { Sulcorebutia } \\
\text { canigueralli } \\
\mathbf{( n}^{\circ} \mathbf{)}\end{array}$ \\
\hline CTRL & $32,67^{\mathrm{b}}$ & $22,83^{\mathrm{b}}$ \\
AS & $39,50^{\mathrm{a}}$ & $31,67^{\mathrm{a}}$ \\
\hline ANOVA & $* *$ & $* * *$
\end{tabular}

One-way ANOVA; n.s. - non significant; $* * *, * * *-$ significant at $\mathrm{P} \leq 0.05,0.01$ and 0.001 , respectively; different letters for the same element indicate significant differences according to Tukey's (HSD) multiple-range test $(\mathrm{P}=0.05)$

Table 4 Evaluation of average germination time on seeds of Rebutia heliosa and Sulcorebutia canigueralli

\begin{tabular}{ccc}
\hline Groups & $\begin{array}{c}\text { Rebutia } \\
\text { heliosa } \\
\text { (days) }\end{array}$ & $\begin{array}{c}\text { Sulcorebutia } \\
\text { canigueralli } \\
\text { (days) }\end{array}$ \\
\hline CTRL & $21,17^{\text {a }}$ & $24,83^{\text {a }}$ \\
AS & $17,83^{\mathrm{b}}$ & $22,33^{\text {a }}$ \\
\hline ANOVA & $*$ & $\mathbf{n s}$
\end{tabular}

One-way ANOVA; n.s. - non significant; ${ }^{* * *},{ }^{* *}$ - significant at $\mathrm{P} \leq 0.05,0.01$ and 0.001 , respectively; different letters for the same element indicate significant differences according to Tukey's (HSD) multiple-range test $(\mathrm{P}=0.05)$
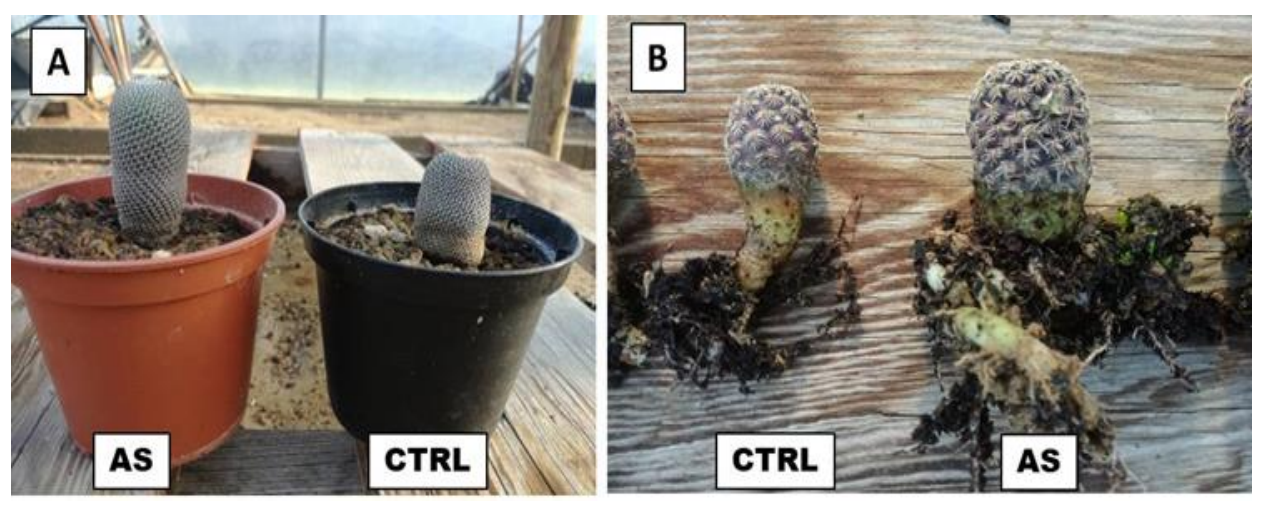

Figure 2 Effect of Ascophyllum nodosum extract on plant height of Rebutia heliosa (A) and roots biomass of Sulcorebutia canigueralli (B). Legend: (CTRL) control; (AS) Ascophyllum nodosum 10\% 

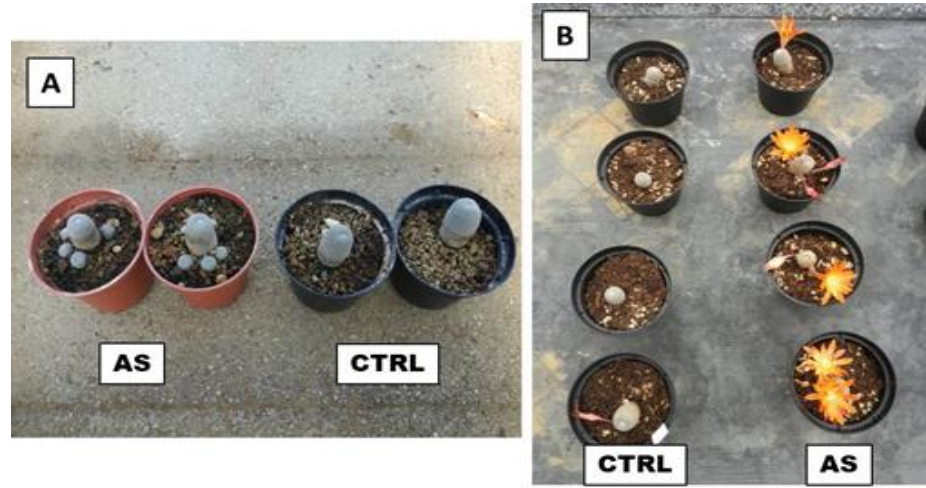

Figure 3 Effect of Ascophyllum nodosum extract on suckers (A) and flowers number (B) of Rebutia heliosa Legend: (CTRL) control; (AS) Ascophyllum nodosum 10\%

\section{Discussion}

In recent years there has been a trend towards greater efficiency in the use of synthetic fertilisers and a return to the use of algae based products to improve plant quality and the ability to use nutrients [10]. Since the fifties, the use of algae has been supplanted by the use of commercial extracts capable of providing useful molecules to plants. The effectiveness of algae as biostimulants depends on the composition and concentration of compounds that can improve plant metabolism under stressful conditions. Among the hormones most commonly found in algae extracts are cytokinins, auxins, gibberellins and abscissic acid as well as other hormone-like substances [11,12].

Experimental evidence has shown that the use of algae extracts administered to plants has positive effects on plant growth, health and crop production caused by the presence of carbohydrates, amino acids, vitamins and hormone-like substances in algae. The substances in the algae can stimulate plant metabolism and improve tolerance to biotic and abiotic stress $[13,14]$.

In this experiment on Rebutia heliosa and Sulcorebutia canigueralli the ability of algae, in particular Ascophyllum nodosum, to significantly improve and increase plant quality, root growth, flower life and seed germination as found on other succulent species is confirmed [15].

Effects certainly due to an improvement in the nutritional status of the plants induced by an increase in nutrient assimilation, which manifests itself in increased stress tolerance.

The variability of the results can be determined by the heterogeneity of the raw material or by the manufacturing processes and by the type of application that can determine a different physiological response [16].

For a better use of algae it is good to know the production conditions and the plant species on which you want to intervene, but the application by foliar or in the growing medium can certainly improve the growth and quality of plants. Positive effects can be found especially on plant species that have difficulty in germinating, rooting and flowering or as in this experiment on plants that are slow to grow or have difficulty in being grown in greenhouses and in climatic conditions different from those in which they originated.

\section{Conclusion}

The test has shown that the use of Ascophyllum nodosum algae can improve the growth and flowering of cacti such as Rebutia heliosa and Sulcorebutia canigueralli, in particular by significantly increasing the height of the plants, the vegetative and radical part, the number of flowers, the duration of flowering, the circumference of the plants. It also highlights significant improvements in seed germination percentage and average germination time. Interesting aspects on the use of algae as biostimulants, especially on plants that normally come from extreme environments and that usually do not adapt well to the substrates and growing conditions of our greenhouses. 


\section{Compliance with ethical standards}

\section{Acknowledgments}

The research is part of the project "Micronaturale": innovative techniques with low environmental impact for the cultivation and protection of plants.

\section{Disclosure of conflict of interest}

The author declares no conflict of interest.

\section{Statement of ethical approval}

The present research work does not contain any studies performed on animals/humans subjects

\section{References}

[1] Barthlott W and Hunt D. (2000). Seed diversity in the Cactaceae, subfamily Cactoideae (Succulent Plant Research, vol. 5). D. Hunt, Sherborne, UK. 173

[2] Cecarini M. (2011). Piante grasse. Le cactacee. Guida pratica completa per coltivare, riconoscere, moltiplicare, difendere, curare le piante grasse.

[3] Amariz A, Lima MAC, Trindade DCG, Santos ACN and Ribeiro TP. (2010). Recobrimentos à base de carboximetilcelulose e dextrina em mangas 'Tommy Atkins' armazenadas sob refrigeração. Ciência Rural, Santa Maria, 40(10), 2199-2205

[4] Plotto A, Narciso JA, Rattanapa-None N and Baldwin EA. (2010). Surface treatments and coating to maintain fresh-cut mango quality in storage. Journal of the Science of Food and Agriculture, London, 90, 2333-2341.

[5] Souza ML, Morgado CMA, Marques KM, Mattiuz CFM and Mattiuz BH. (2011). Pós-colheita de mangas 'Tommy Atkins' recobertas com quitosana. Revista Brasileira de Fruticultura, Jaboticabal, 337-343. Volume especial.

[6] Carvalho CRL, Mantovani DMB, Carvalho PRN and Moraes RM. (1990). Análises químicas dos alimentos. Campinas: Instituto de Tecnologia de Alimentos, 121 p. (Manual Técnico).

[7] Jayraman J, Norrie J and Punja ZK. (2011). Commercial extract from the brown seaweed Ascophyllum nodosum reduces fungal diseases in greenhouse cucumber. Journal of Applied Phycology, Dordrecht, 23, 353-361.

[8] Khan W, Rayirath UP, Subramanian S, Jithesh MN, Rayorath P, Hodges DM, Critchley AT, Craigie JS, Norrie J and Prithiviraj B. (2009). Seaweed extracts as biostimulants of plant growth and development. Journal of Plant Growth and Regulation, Chennai, 28, 389-399.

[9] Craigie JS. (2011). Seaweed extract stimuli in plant science and agriculture. Journal of Applied Phycology, Dordrecht, 23, 371-393.

[10] Basavaraja PK, Yogendra ND, Zodape ST, Prakash R and Ghosh A. (2018). Effect of seaweed sapa s foliar spray on growth and yield of hybrid maize. Journal of Plant Nutrition, 41(14), 1851-1861.

[11] Beckett RP, Mathegka ADM and Van Staden J. (1994). Effect of seaweed concentrate on yield of nutrient stressed tepary bean (Phaseolus acutifolius Gray). Journal of Applied Phycology, 6, 429-430.

[12] Chouliaras V, Tasioula M, Chatzissavidis C, Therios I and Tsabolatidou E. (2009). The effects of a seaweed extract in addition to nitrogen and boron fertilization on productivity, fruit maturation, leaf nutritional status and oil quality of the olive (Olive europaea L.) cultivar Koroneiki. Journal of the Science of Food and Agriculture, 89( 6), 984-988.

[13] Chrysargyris A, Xylia P, Anastasiou M, Pantelides I and Tzortzakis N. (2018). Effect of Ascophyllum nodosum seaweed extracts on lettuce growth, physiology and fresh cut salad storage under potassium deficienc. Journal of the Science of Food and Agriculture, 98(15), 5861-5872.

[14] Hurtado AQ and Critchley AT. (2018). A review of multiple biostimulant and bioeffector benefits of AMPEP, an extract of the brown alga Ascophyllum nodosum, as applied to the enhanced cultivation and micropropagation of the commercially important red algal carrageenophyte Kappaphycus alvarezii and its selected cultivars. Journal of Applied Phycology, 30(5), 2859-2873. 
[15] Prisa D. (2019). Possible use of Spirulina and Klamath algae as biostimulantsin Portulaca grandiflora (Moss Rose). World Journal of Advanced Research and Reviews, 2019, 3(2), 1-6.

[16] Jayaraman J, Norrie J and Punja ZK. (2011). Commercial extract from the brown seaweed Ascophyllum nodosum reduces fungal diseases in greenhouse cucumber. Journal of Applied Phycology, 23(3), 353-361.

\section{How to cite this article}

Prisa D. (2020). Ascophyllum nodosum extract on growth plants in Rebutia heliosa and Sulcorebutia canigueralli. GSC Biological and Pharmaceutical Sciences, 10(1), 39-45. 